\title{
Hypersensitive Reactivity of Various Host and Nonhost Plant Leaves to Cell Wall Components and Soluble Glucan Isoalted from Phytophthora infestans
}

\author{
Noriyuki DoKe**, Susumu SaKaI**, and Kohei TomiYama** \\ 道家紀志**・酒井 進**・冨山宏平**：Phytophthora infestans の細胞壁成分と可溶性 \\ グルカンに対する各種宿主及び非宿主植物葉の過敏感反応能
}

\begin{abstract}
Cell wall components (CW) and water soluble glucan (WSG) from Phytophthora infestans, that have been known to elicit and suppress the hypersensitive response of potato tissue, respectively, were applied to leaves of various host and nonhost plants by rubbing with carborundum to study how they respond hypersensitively to the fungal components. Leaves of Solanaceae plants : potato, tomato, sweet pepper, egg plant, red pepper, datura, and Japanese bladder cherry ; Leguminosae plants : soybean, kidneybean, garden pea, broad bean, and cowpea ; and Lileaceae plants : onion, welsh onion, and white trumpet lily showed necrotic lesions $24 \mathrm{hr}$ after treatment with $\mathrm{CW}$. On the contrary, leaves of Solanaceae plants : tobacco ; Chenopodiaceae plants : goose-foot, white-goose-foot, spinach, and beet ; Compositae plants : chrysanthemum, garland chrysanthemum, and lettus ; Cruciferae plants : cabbage, chinese cabbage, turnip, and radish ; Graminea plants : rice, barley, wheat, and corn ; and Rosaceae plants : strawberry, Japanese pear, and rose did not show any visible necrotic cells within $48 \mathrm{hr}$ after the treatment with $\mathrm{CW}$. Red pepper and Japanese bladder cherry (Solanaceae), soybean and cowpea (Leguminosae) and white goose-foot (Chenopodiaceae) showed almost the same necrotic lesion by treatment with WSG as those by CW. In the cases of plant leaves in which necrotic lesions were elicited by these fungal components, an abnormal leakage of electrolytes occurred within $5 \mathrm{hr}$ after treatment with them. These resuslts suggested that specific families of plant have a nature to respond hypersensitively to the cell wall components and water soluble glucan of $P$. infestans regardless of host or nonhost relationship.

(Received April 27, 1979)
\end{abstract}

\section{Introduction}

It has reported that some fungal components elicited the hypersensitive reaction of host plants including tissue browning and accumulation of phytoalexins in several host-parasite system $1,2,3,4,5,11,13,14,18)$. In potato-Phytophthora infestans system, sonicate of mycelia ${ }^{6,7,12,19,20)}$, homogenate of zoospores ${ }^{10)}$ and cell wall components isolated from $P$. infestans ${ }^{5,9,15,16)}$ elicited the hypersensitive reaction in potato tissues regardless of their resistance genes. It was also reported that autoclaved sonicate of Oomycetes ( $P$. infestans, $P$. parasitica, Phythium aphanidermatum, Achlga flagelata

* Supported in part by Grant from the Ministry of Education, Science and Culture of Japan (No 336005)

** Plant Pathology Laboratory, Faculty of Agriculture, Nagoya University, Nagoya, Japan 名古屋大学農学部 
and Aphanomyces euteiches) that contained glucan cellulose as major cell wall components elicited the accumulation of phytoalexin in potato tuber tissues, but those of other fungi containing glucan-chitin, glucan-chitosan, chitin-mannan and glucan-mannan did not ${ }^{17)}$. Water soluble glucan fraction isolated from $P$. infestans did not elicit the hypersensitive reaction in potato tuber tissues while the glucan had an activity to suppress the hypersensitive reaction elicited by infection with incompatible races or treatment with the cell wall fraction of $P$. infestans $6,7,8,9,12)$.

On the other hand, glucan isolated from $P$. megasperma var sojae elicited the accumulation of phytoalexin in soybean tissue ${ }^{2,3)}$. These experimental evidences suggested that some polysaccharide components of fungi may elicit the hypersensitive reaction in some particular plant tissues.

In the present paper, what sort of families, genera and species of host or nonhost plants have hypersensitive reactivity to polysaccharide fractions of $P$. infestans was investigated to know whether there are a specificity in recognition of fungal components by plant tissues or not.

\section{Materials and Methods}

Plant. The following plants were used. Solanaceae : potato (Solanum tuberosum L. vr. Irish Cobbler, Rishiri, Hokkai 53, and Pentland Ace), tomato (Licopericicum esculentum Mill vr. Hard Top, Ogata-Fukuju, and Satan), egg plant (Solanum melongena L. vr. Kokuyo, Senryo, Manryo), sweet pepper (Capcicum frutescence L. vr. California Wandar, Ace, and New Ace), red pepper (Capcicum annuum L. vr. Shishito), tobacco (Nicotiana tabacum L. vr. Sumsun NN and Bright Yellow and Nicotiana glutinosa L.), Datura (Datura stramonium L.), and Japanese bladder cherry (Physalis alkekengi L. vr. francheti (Mast) Hurt.). Leguminosae : soybean (Glycine max Merr. vr. Tanba-black, Ogaki-brown, and Toei-white), kindney bean (Phaseolus vulgaris L. vr. Kairyo-otebo and Tebo), Pea (Pisum sativum L. vr. Sanukinagasaya and Wase), cowpea (Dolichos sesquipendalis Wight vr. Kurodanesanjaku, Juroku and Black-eye). Cucurbitaceae : water melon (Citrullus vulgaris Schrad vr. Shinfuji), melon (Cucumis melo L. vr. Mizuhoaohi), cucumber (Cucumis sativus L. vr. Sagamihangetsu), pumpkin (Cucubita moshata Duch. vr. Hyuga No 14) and bottle gourd (Legenavia sincerabia Stan. vr. hispenda Hara cv. Daimaru). Chenopodiceae : goose-foot (Chenopodium album L. vr. centroruburum Makino), white goose-foot (Chenopodium album L.), spinach (Spinacea oleracea L. vr. Heian-hiyoshimaru), and beet (Beta vulgaris L. vr. Donyu No 2). Liliaceae : onion (Allium cepa L. vr. OK-kidama), welsh onion (Allium fistulosum L. vr. Kujofutonegi), and white trumpet lily (Lilium auratum L.). Compositae : chrysanthemum (Chrisantemum molifolium L.), garland chrisanthemum (Chrisanthemum coronarium L. vr. Taiyo), lettus (Lactuca sativa L. vr. Alpen). Cruciferae : cabbage (Brassica oleracea var captata L. vr. Alpen), chinese cabbage (Brassica pekinensis Rupr. vr. Shinkashin), turnip (Brassica rapa L. vr. Tokyo-tokinashi), radish (Raphanus sativus L. vr. Natsuminowase No 1). Gramineae: rice (Oryza sativa vr. Asahi), barley (Hordium vulgare $\mathrm{L}$ ), wheat (Triticum vulgare L.) and corn (Zea mays L. vr. Golden crossbantum). Rosaceae : strawberry (Fragaria chiloensis Duch. var. annansa Bail) and Japanese pear (Pyrus serotina Rehder vr. Chojuro). In the case of no description, unknown cultivated varieties were used. The 3rd to 4 th leaves from the top ones of Solanaceae, Chenopodiaceae, Compositae, and Graminea plants, first true leaves of Leguminosae and Cucubitaceae plants and appropriate developed leaves of the other plants were used.

Extraction of fungal components. The methods described in a previous paper 
were used to isolate cell wall components ${ }^{5,9,15,16)}$ and water soluble glucan ${ }^{6,7)}$ of $P$. infestans mycelia (race 0 and race 1 ) that were grown on a rye seed-extract liquid medium for 13 days at $18 \mathrm{C}$. The formar and latter compounds were known to be a hypersensitivity-eliciting and inhibiting factors of potato tuber tissues, respective$1 y^{6,7,9,12)}$.

Treatment with fungal component. Surface of detached leaves was washed by tap water and wiped with filter paper. Solution containing cell wall components or water soluble glucan $(5 \mathrm{mg} / \mathrm{ml})$ were applied on the upper surface of leaves by rubbing gently with a painting blash with carborundum (600 meash). The treated leaves were incubated on a wet filter-paper in a petri dish at $25 \mathrm{C}$ under a light condition (ca. 2,000 lux).

Observation of cell necrosis. Necrotic cells in all leaves were observed under a light microscope $(\times 150)$ and the number of necrotic cell group per a definite area was counted 24 and $48 \mathrm{hr}$ after treatment. Two or three leaves of each plant were used in each experiment and the experiment was repeated at least three times.

Measurement of loss of electoryte. The loss of electrolytes from major leaves treated with the mycelial components was determined as follows : after measuring area of each leaf, the leaves were treated with the mycelial components as described above and kept in a moist chamber for $2 \mathrm{hr}$, and then the leaves were immersed in $50 \mathrm{ml}$ of deionized distilled water. Electric conductivity of the immersion water $(\mu$ mhos $/ \mathrm{cm}^{2}$ leaf area) was measured by a electric conductivity meter (Conductivity bridge RC 216B2, Beckman Instrment Inc.) at intervals after treatment.

\section{Results}

\section{Elicitation of necrotic cells}

Leaves of 43 plants ( 9 families, 13 genera, 43 species) were treated with cell wall components and water soluble glucan isolated from mycelia of $P$. infestans (race 0 and 1). Leaves of Solanaceae plants (potato, tomato, egg plant, sweet pepper, datura and Japanese bladder cherry) (Table 1), Leguminosae plants (soybean,kidney bean, pea, broad bean and cowpea) (Table 2), Lileaceae plants (onion, welsh onion and white trumpet lily) and Chenopodiaceae plants (white goose-foot) (Table 3)

showed necrotic lesions $24 \mathrm{hr}$ after treatment with the cell wall components. In most of the cases the necrotic lesion was made up of 3 to 10 browned cells. Treatment with water soluble glucan elicited necrotic lesions in the leaves of red pepper (Solanaceae), soybean (Leguminosae), cowpea (Leguminosae) and white goose-foot (Chenopodiaceae) (Table 1-3). On the other hand, leaves of Solanaceae plants (tobacco), Cucubitaceae plants (water melon, cucumber, pumpkin, and bottle gurd), Chenopodiaceae plants (goose-foot, spinach, and beet), Compositae plants (crysanthemum, lettus and garland chrysanthemum), Cruciferae plants (cabbage, chinese cabbage, Japanese radish and turnip), Gramineae plants (rice, barley, wheat and corn) and Rosaceae plants (strawberry, Japanese pear and rose) showed no visible necrotic lesions $72 \mathrm{hr}$ after the treatments with both the cell wall components and water soluble glucan (Table 1-3).

In all the cases that necrotic lesions were elicited by the fungal components, visible lesions were already observed $24 \mathrm{hr}$ after the treatment. However, thereafter the necrotic lesions did not develop larger during incubation at least until $72 \mathrm{hr}$ after the treatment. There was no significant difference in the response of plant leaves to the fungal components isolated from race 0 and 1 of $P$. infestans. It was also found that there was no significant difference in the mode of response of leaves 
Table 1. Response of Solanaceae plant leaves to cell wall components and water soluble glucan isolated from Phytophthora infestans mycelia

\begin{tabular}{|c|c|c|c|c|c|}
\hline \multirow{3}{*}{ Solanaceae plant } & \multirow{3}{*}{ Variety } & \multicolumn{4}{|c|}{ Necrotic lesion ${ }^{a}$} \\
\hline & & \multicolumn{2}{|c|}{ Cell wall comp. } & \multicolumn{2}{|c|}{ Soluble glucan } \\
\hline & & Race 0 & Race 1 & Race 0 & Race 1 \\
\hline \multirow[t]{4}{*}{ Potato (Solunum tuberosum L.) } & Irish Cobbler & + & + & - & - \\
\hline & Rishiri & + & + & - & - \\
\hline & Hokkai 53 & + & + & - & - \\
\hline & Pentland Ace & + & + & - & - \\
\hline \multirow[t]{3}{*}{ Tomato (Lycoperisicum esculentum Mill.) } & Hard Top & + & + & - & - \\
\hline & Ogata Fukuju & + & + & - & - \\
\hline & Satan & + & + & - & - \\
\hline \multirow[t]{3}{*}{ Egg plant (Solunumm elongena L.) } & Kokuyo & + & + & - & - \\
\hline & Senryo & + & + & - & - \\
\hline & Manryo & + & + & - & - \\
\hline \multirow[t]{3}{*}{ Sweet pepper (Capcicum frutescence L.) } & California Wander & + & + & - & - \\
\hline & Ace & + & + & - & - \\
\hline & New Ace & + & + & - & - \\
\hline Red pepper (Capacicum annuиm L.) & Shishito & + & + & + & + \\
\hline \multirow[t]{2}{*}{ Tobacco (Nicotiana tabacum L.) } & Sumsun NN & - & - & - & - \\
\hline & Bright Yellow & - & - & - & - \\
\hline (Nicotiana glutinosa L.) & & - & - & - & - \\
\hline Datura (Datura stramonium L.) & & + & + & - & - \\
\hline $\begin{array}{l}\text { Japanese bladder cherry (Rhysalis } \\
\text { alkekengi L.) }\end{array}$ & Francheti & + & + & + & + \\
\hline
\end{tabular}

a Observed 24 and $48 \mathrm{hr}$ after treatment. + : Necrotic lesions were observed.

Table 2. Response of Leguminosae plant leaves to cell wall component and soluble glucan isolated from Phytophthora infestans mycelia

\begin{tabular}{|c|c|c|c|c|c|}
\hline & & \multicolumn{4}{|c|}{ Necrotic lesion ${ }^{a}$} \\
\hline \multirow{2}{*}{\multicolumn{2}{|c|}{ Leguminosae plant }} & \multicolumn{2}{|c|}{ Cell wall comp. } & \multicolumn{2}{|c|}{ Soluble glucan } \\
\hline & & Race 0 & Race 1 & Race 0 & Race 1 \\
\hline \multirow[t]{3}{*}{ Soybean (Glycine max Merr.) } & Tanba-black & + & + & + & + \\
\hline & Ogaki-brown & + & + & + & + \\
\hline & Toei-white & + & + & + & + \\
\hline \multirow[t]{2}{*}{ Kidney bean (Phaseolus vulgaris L.) } & Kairyootebo & + & + & - & - \\
\hline & Tebo & + & + & - & - \\
\hline \multirow[t]{3}{*}{ Gardenpea (Pisum sativum L.) } & Waiseiakabana & + & + & - & - \\
\hline & Kinusaya & + & + & - & - \\
\hline & Frenchosaya & + & + & - & - \\
\hline \multirow[t]{2}{*}{ Broad bean (Vicia fava L.) } & Sankingasaya & + & + & - & - \\
\hline & Wase & + & + & - & - \\
\hline \multirow[t]{3}{*}{ Cowpea (Dolichos sesquipendalis Wight) } & Kurodanesanjaku & + & + & + & + \\
\hline & Juroku & + & + & + & + \\
\hline & Blackeye & + & + & + & + \\
\hline
\end{tabular}

a Observed 24 and $48 \mathrm{hr}$ after treatment. $+:$ Necrotic lesions were observed 
Table 3. Response of Cucubitaceae, Chenopodiaceae, Liliaceae, Compositae, Cruciferae, Graminea and Rosaceae plant leaves to cell wall component and soluble glucan isolated from Phytophthora infestans mycelia

\begin{tabular}{|c|c|c|c|c|}
\hline \multirow{3}{*}{ Plant } & \multicolumn{4}{|c|}{ Necrotic lesion ${ }^{a}$} \\
\hline & \multicolumn{2}{|c|}{ Cell wall comp. } & \multicolumn{2}{|c|}{ Soluble glucan } \\
\hline & Race 0 & Race 1 & Race 0 & Race 1 \\
\hline \multicolumn{5}{|l|}{ Cucubitaceae } \\
\hline Watermelon (Citrullus vulgaris Schrad) & - & - & - & - \\
\hline Melon (Cucumis melo L.) & - & - & - & - \\
\hline Cucumber (Cucumis sativas L.) & - & - & - & - \\
\hline Pumpkin (Cucubita moshata Duch.) & - & - & - & - \\
\hline Bottle gourd (Lagenavia sicerabia Stan. var Hispeda Hara) & - & - & - & - \\
\hline \multicolumn{5}{|l|}{ Chenopodiaceae } \\
\hline $\begin{array}{c}\text { Goose-foot (Chenopodium album L. var. centrorubrum } \\
\text { Makino) }\end{array}$ & - & - & - & - \\
\hline White goose-foot (Chenopodium album L.) & + & + & + & + \\
\hline Spinach (Spinacea oleracea L.) & - & - & - & - \\
\hline Beet (Beta vulgaris L.) & - & - & - & - \\
\hline \multicolumn{5}{|l|}{ Liliaceae } \\
\hline Onion (Allium cepa L.) & + & + & - & - \\
\hline Welsh onion (Allium fistulosum L.) & + & + & - & - \\
\hline White trumpet lily (Lilium auratum L.) & + & + & - & - \\
\hline \multicolumn{5}{|l|}{ Compositae } \\
\hline Chrisanthemum (Chrisanthemum molifolium Ram.) & - & - & - & - \\
\hline Garland chrysanthemum (Chrisanthemum coronarium L.) & - & - & - & - \\
\hline Lettus (Lactuca sativa L.) & - & - & - & - \\
\hline \multicolumn{5}{|l|}{ Gruciferae } \\
\hline Cabbage (Brassica oleraceae var. capita L.) & - & - & - & - \\
\hline Chinese cabbage (Brassica pekinensis Rupr.) & - & - & - & - \\
\hline Turnip (Brassica rapa L.) & - & - & - & - \\
\hline Radish (Raphnus sativas L.) & - & - & - & - \\
\hline \multicolumn{5}{|l|}{ Graminea } \\
\hline Rice (Oryzae sativa L.) & - & - & - & - \\
\hline Barley (Hordium vulgare L.) & - & - & - & - \\
\hline Wheat (Tritichum vulgare L.) & - & - & - & - \\
\hline Corn (Zea mays L.) & - & - & - & - \\
\hline \multicolumn{5}{|l|}{ Rosaceae } \\
\hline Strawberry (Fragaria chiloensis Duch. var ananasa Bail) & - & - & - & - \\
\hline Japanese pear (Pyrus serotina Rehder) & - & - & - & - \\
\hline
\end{tabular}

a Observed 24 and $48 \mathrm{hr}$ after treatment. + : Necrotic lesions were observed

to the fungal components between cultivated varieties in the same species. When these leaves were treated with the fungal components without rubbing with carborundum using painting brash, a small number of necrotic lesions was found at the site of stomata. The rubbing with the brash with distilled water containing carborundum did not cause any visible necrotic cells.

\section{Loss of electrolyte}

To measure a response of leaves to the fungal components before necrotic lesions appeared, loss of electrolytes from the leaves of potato, sweet pepper, tomato, tobacco, 


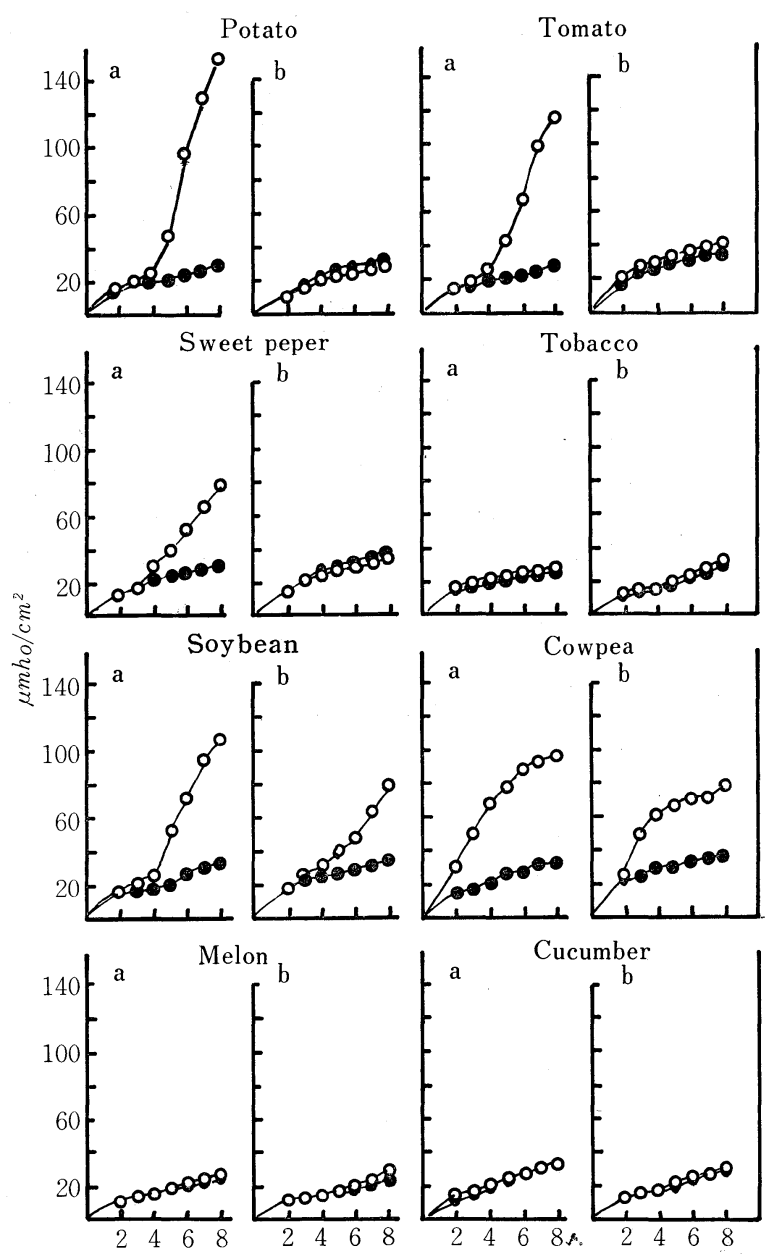

Fig. 1. Leakage of electrolytes from plant leaf tissues treated with cell wall components (a) or water soluble glucans (b) isolated from Phytophthora infestans (race 1). The following plant leaves were used : potato (cv. Rishiri), tomato (cv. Hard Top), Sweet pepper (cv. New Ace), Tobacco (cv. Sumsun NN), Soybean (cv. Tanbablack), Cowpea (cv. Kurodanesanjaku), melon (cv. Mizuhoaoi), cucumber (cv. Sagami-hangetsu). Electric conductivity of the immersion water is expressed as $\mu \mathrm{mhos} / \mathrm{cm}^{2}$ leaf area in $50 \mathrm{ml}$ of deionized distilled water. Open circles : treated, filled circles :control. soybean, cowpea, melon and cucumber treated with the fungal components were determined (Fig. 1). All plant leaves that responded to the fungal components with showing necrotic lesions later released electrolytes from leaves more than nontreated ones almost 4 to $5 \mathrm{hr}$ after the treatment when the necrotic cells has not yet appeared. The leakages from the leaves that any necrotic lesion was induced by the treatment with the fungal components were almost the same as that of non-treated leaves (Fig. 1).

\section{Discussion}

Leaves of the most of Solanaceae and Leguminosae plants tested in the present experiments showed necrotic lesions when treated with cell wall components isolated from $P$. infestans that is known as an eliciter of the hypersensitive reaction in potato tuber tissues ${ }^{5,9,15,16)}$, and the reactions were accompanied by an increased loss of electrolytes before appearance of the necrotic lesions (Fig. 1). Plant leaves belonging to other families did not respond to the compounds with appeareance of necrotic lesions and loss of electrolytes with a few exceptions (Table 3 ). These results indicated that such reactivity of plant leaves to the cell wall components of $P$. infestans is specific to Solanaceae and Leguminosae plants.

Very restricted plants (soybean, cowpea, red pepper, Japanese

bladder cherry and goose-foot) among those tested reacted hypersensitively to water soluble glucan fraction from $P$. infestans, followed by appearance of necrosis of the treated tissue (Table 1, 2, and 3). The glucan has been characterized by glucan containing $\beta-(1 \rightarrow 3)$ and $\beta-(1 \rightarrow 6)$ linkage and 17 to 23 glucose units ${ }^{6,7)}$.

It has been reported that potato tissues have ability to respond to the sonicate of certain species of fungi having glucan cell wall, but not to those of fungi having other kinds of polysaccharides as major cell wall components ${ }^{17)}$, and also that glucan 
fraction with $\beta-(1 \rightarrow 3)$ linkage isolated from $P$. megasperma var sojae elicited accumulation of phytoalexin in soybean tissues ${ }^{23}$. In the case of water soluble glucan from $P$. infestans suppressed the hypersensitive reaction in potato tuber tissue elicited by infection or treatment with the cell wall components ${ }^{6,7,9)}$, however, did not cause any sign of necrosis or accumulation of phytoalexin. These resuslts strongly suggest that plants may have reactivity to a specific group of mycelial wall components, and the physiologically active site of the mycelial components may be specific sugar residues or structures of polysaccharides consisting the mycelial wall.

Wound caused by carborundum was necessary to make the treatment of the leaves with mycelial componts sufficiently effective. When the treatment was done without carborundum, necrosis occurred only in a few cells surrounding stomata. These observation indicated that in the case of the adult leaf surface composed of wax, cuticle and so on, the information of the mycelial components could hardly pass through it into cells. This presumption was also supported by the fact that protoplasts prepared from potato tissues reacted hypersensitively very soon after the treatment with the mycelial wall components (Doke and Tomiyama,unpublished).

The authors are grateful to Messrs Y. Nishibe and Y. Umemura in Hokkaido Agricultural Experimental Station and Dr. Y. Kono, Crop Science Laboratory, Faculty of Agriculture, Nagoya University for generous supply of potatoes and bean seeds, respectively.

\section{Literature cited}

1. Anderson, A. J. (1978). Phytopathology $68: 189-194$.

2. Anderson, A. J. and Albersheim, P. (1975). Plant Physiol. 56 : 286-291.

3. Ayers, A., Ebel, J., Finelli, F., Berger, N. and Albersheim, P. (1976). Plant Physiol. 57 : 751-759.

4. Cruickshank, I. A. M. and Perrin, D. R. (1968). Life Sci. $7: 449-458$

5. Currier, W. W. (1974). Ph D. Thesis, Purdue University, Lafaette, Indiana. $113 \mathrm{pp}$.

6. Doke, N., Garas, N. A. and Kuć, J. (1977). Proc. Am. Phytopath. Soc. 4:165 (Abstr.).

7. Doke, N., Garas, N. A. and Kuć. J. (1979). Physiol. P1. Pathol. 15 (in press).

8. Doke, N, Garas, N. A., and Kuć, J. (1979). Phytopathology (in press).

9. Doke, N., Lisker, N. and Kuc, J. (1978). Ann. Phytopath. Soc. Japan $44: 93$ (Abstr.).

10. Doke, N., Tomiyama, K., Lee, H. S. Nishimura, N. and Matsumoto, N. (1976). In Biochemistry and Cytology of Plant-Parasite Interaction (Tomiyama, K. et al. eds.). Kodansha Ltd. Tokyo. pp 157-167.

11. Frank, J. A. and Paxton, J. D. (1971). Phytopathology 61 : 954-956.

12. Garas, N. A., Doke, N. and Kuć, J. (1979). Physiol. Pl. Pathol. 15 (in press).

13. Keen, N. T. (1975). Science $187: 74-75$.

14. Keen, N. T., Partridge, J. E. and Zaki, A. T. (1972). Phytopathology $62: 768$.

15. Kuć, J., Durrier, W. W. Elliston, J. and McIntyre, J. (176). In Biochemistry and Cytology of Plant-Parasite Interaction (Tomiyama, K. et al. eds.), Kodansha Ltd., Tokyo. pp. 168-180.

16. Kuć., J. Currier. W. W., and Shih, M. J. (1976). In Biochemical Aspects of Plant-Parasite Relationships (Friend, J et al. eds.). Academic Press, London and New York. pp. 225-237.

17. Lisker, N. and Kuć, J. (1977). Phytopathology $67:$ 1356-1359.

18. Shiraishi, T. Oku, H., Yamashita, M. and Ouchi, S. (1978). Ann. Phytopath. Soc. Japan. $44: 659-665$.

19. Varns, J. L., Currier, W. W. and Kuć, J. (1971). Phytopathology 61 : 968-971.

20. Varns, J. L. Kuć, J. and Williams, E. B. (1971). Ibid. 61 : 174-177. 
和 文 摘 要

Phytophthora infestans の細胞壁成分之可溶性グルカンに対する 各種宿主及び非宿主植物葉の過敏感反応能

道家紀志・酒井 進・冨山宏平

ジャガイモ組織に過敏感反応を誘導する Phytophthora infestans の細胞壁成分（CW）とその誘導を 抑制する水溶性グルカン（WSG）を各種宿主及び非宿主植物葉に，カーボランダムによる摩擦塗布処理をし， 葉組織の過敏感反応性を調べた。ナス科のジャガイモ, トマト, ピーマン, ナス, トウガラシ, ダチュラ, ホーズキ, マメ科のダイズ, インゲン, エンドウ, ソラマメ, ササゲ, ユリ科のタマネギ, ネギ, テッポー ユリの葉は $\mathrm{CW}$ に反応し, 処理後 24 時間後には褐変え死細胞を生じた。ナス科のタバコ, アカザ科の 4 種, キク科の 3 種, 十字花科の 4 種, イネ科の 4 種, バラ科の 3 種の各植物葉はいずれも, 処理後72時間以内に も肉眼的観察可能な細胞の反応は示さなかった。トウガラシ，ホーズキ，ダイズ，ササゲ及びシロザの葉は $\mathrm{CW}$ と同様に, WSG とも反応し褐変え死細胞を生じた。それらの処理により過敏感反応を起し得る葉は, 処理後, 5 時間以内に異常な電解質の漏出を起した。これらの結果は, 特定な科に属する植物が, P. infestans の CW 及び WSG に対して, 宿主・非宿主とにかかわりなく過敏感反応を起す性質を持つことを示唆 した。 